\title{
Clothing fashion brands
}

DOI: $10.35530 / 1 T .071 .05 .1768$

\section{ABSTRACT - REZUMAT}

\section{Clothing fashion brands}

In the fashion, industry brands are especially important, because the competition is high, and companies need to attract new customers and keep them. Successful branding requires a good knowledge of consumers and their purchasing processes. Brands have an important function in the fashion world, both for businesses and consumers. The brand is assured to the consumers by the quality and by acquiring some image and status in the company. A strong brand makes a profit for the company. In addition, a strong brand enables setting high prices and expansion of product range and introducing new products.

In the survey, we wanted to examine the behaviour of customers in the clothing brands in the Slovenian market. We used a survey questionnaire to get the appropriate answers.

The survey found that most respondents want to buy clothes in larger shopping centres and in the Internet, most often during the sale after the season.

Keywords: brand, fashion, consumer's behaviour, fashion clothes

\section{Branduri de modă pentru îmbrăcăminte}

În modă, brandurile din industrie sunt deosebit de importante, deoarece concurența este mare, iar companiile trebuie să atragă noi clienți și să-i păstreze. Brandingul de succes necesită o bună cunoaștere a consumatorilor și a proceselor de cumpărare ale acestora. Brandurile au o funcție importantă în lumea modei, atât pentru companii, cât și pentru consumatori. Brandul asigură consumatorilor o înaltă calitate și dobândirea unei anumite imagini și statut în companie. Un brand puternic face profit pentru companie. În plus, un brand puternic permite stabilirea unor prețuri ridicate și extinderea gamei de produse, precum și introducerea de produse noi pe piață.

În cadrul sondajului, am dorit să analizăm comportamentul clienților în ceea ce privește brandurile de modă pentru îmbrăcăminte de pe piața slovenă. Am folosit un chestionar de sondaj pentru a obține răspunsurile adecvate.

Sondajul a constatat că majoritatea respondenților doresc să cumpere produse de îmbrăcăminte din centre comerciale mai mari și de pe internet, cel mai adesea în timpul reducerilor de la finalul sezonului.

Cuvinte-cheie: brand, modă, comportamentul consumatorilor, îmbrăcăminte la modă

\section{INTRODUCTION}

Fashion marketing uses a number of techniques and business philosophy that focus on actual and potential buyers of clothing and fashion accessories in order to achieve long-term goals of the organization [1].

In the fashion industry, the brand is a means of identification with certain fashion trends, styles and ways of life. A good brand has a clear identity.

Developing and building a brand is a strategically oriented activity. Understanding relationships between users and their fashion brands is essential for the marketing, as these links significantly affect the profitability of the company [2].

In the clothing industry fashion is dominant, which is why this industry is so specific and constantly under the influence of fashion culture. In the world, fashion and design are the leading European clothing industries. From the industry's point of view, a limited timeframe implies the increased need for flexibility in production, permitting continuous introduction of new lines and collections to the market, to satisfy the continuously evolving interests and expectations of consumers [3].

The trend of fashion development focuses on emphasizing comfort, focusing on light, breathable and warm materials adapted for the season. The advantage of today's fashion is the possibility of a comprehensive combination of clothing [4].

Retailers establish indirect contact between manufacturers and end-users. Their task is to ensure the appropriate volume and structure of supplies at affordable locations, at the same time and at prices that are acceptable to the end consumers $[5,6]$.

\section{FASHION CLOTHING}

Fashion is a unique, exciting and very dynamic market that undoubtedly shows an ability to generate changes of a social or cultural nature [7].

Fashion clothing has been described as possessing something approximating a code it is ever shifting and changing. Fashion clothing is considered a highly 
expressive product and one that is often used to communicate one's image and social position [8, 9]. The consumption of fashion clothing is in fact a sign of a society that focuses on status and is evidence of movement toward a heightened consciousness of the role of consumption and the value clothes play in communication status. Fashion carries status and is symbolic in expressing one's identity and importance [10].

Global mass-market fashion and beauty companies use standardized advertising to sell products to customers around the world to a greater extent than companies in other industries. For fashion companies, a crucial component of success is the presentation of a coherent brand to customers around the world [11].

Consumers are an important part of the fashion system because they can create a valuable influence in the pursuit of sustainability in the fashion industry $[12,13]$.

The brand gives the users psychological satisfaction and represents a greater guarantee of quality than the high price. The user associates the brand with quality, credibility and value. Customers evaluate brand performance differently and are prepared to pay more or less. The brand is therefore nothing more than a group of loyal users, so the activities of the manufacturer are aimed at extending the loyalty period of the selected brand.

\section{THE RELATIONSHIP OF USERS TO THE PURCHASE OF CLOTHING BRANDS}

Today's customer in the developed world does not always have more needs, but has more and more wishes, which are different, special and more demanding. Products, services and processes are becoming much more complex than they used to be. Buyers are becoming increasingly demanding and living in the time of the economy of desire and imagination, and not in the economy of needs. The desire of each designer is to form, the producer (both in the field of yarn, textiles and clothing) produce and the trader will only purchase such products that will be interesting for users. Experience, a comprehensive overview of events and changes in society and a good knowledge of the target group of users are needed for them to understand, anticipate and predict the wishes and needs of users.

In order to find out what is the attitude of consumers to purchasing clothes and the role of brands in the purchase process, we conducted a primary survey in 2018.

The questionnaire was completed by 235 adult individuals. It was submitted via online survey. The majority of respondents are female, with 143 responses, representing $61 \%$. The males represent $39 \%$ of the sample, making 92 responses. Regarding their age, the majority focuses on the age group of 18 to 25 (31\%), followed by the age group of 34 to $41(29 \%)$, then 26 to $33(17 \%)$ age and 42 to 49 years $(14 \%)$.
Only $9 \%$ respondents represent the group with more than 50 years.

First, we wanted to find out the gender, age and amount of monthly income. Then we were interested when and where consumers buy their clothes and what factors are most influencing their purchase of clothing. With the next question, we wanted to find out where shoppers get information about fashion clothing brands. Finally, we were interested in how consumers are loyal to the selected fashion clothes brands and their opinion about trademark counterfeiting.

\begin{tabular}{|c|c|}
\hline \multicolumn{2}{|c|}{ PERSONAL MONTHLY INCOME } \\
\hline Monthly income (euros) & Number of answers (\%) \\
\hline Less than 1000 & 39 \\
\hline From 1000 to 1500 & 45 \\
\hline From 1501 to 2100 & 11 \\
\hline From 2101 to 3000 & 4 \\
\hline More than 3000 & 1 \\
\hline
\end{tabular}

Table 1 shows that for the most respondents the monthly income is between 1,000 and 1,500 euro, and the next most common answer is less than 1,000 euro.

The next question was about the time of buying clothes.

Table 2

\begin{tabular}{|l|c|}
\hline \multicolumn{2}{|c|}{ TIME TO BUY CLOTHES } \\
\hline \multicolumn{1}{|c|}{ Time to buy clothes } & $\begin{array}{c}\text { Number } \\
\text { of answers (\%) }\end{array}$ \\
\hline Only during the post-season sales & 27 \\
\hline Equally throughout the year & 26 \\
\hline Only when I really need something & 21 \\
\hline $\begin{array}{l}\text { Where discounts are offered, but } \\
\text { not in the post-season sales }\end{array}$ & 18 \\
\hline $\begin{array}{l}\text { As soon as when the new } \\
\text { collection come to the market }\end{array}$ & 8 \\
\hline
\end{tabular}

The results in table 2 show that shoppers mostly buy during the post-season sales and equally throughout the year. The least they buy when new collections come to the market.

With the next question, the respondents identified where they most often buy clothes. We got the following answers.

Most of them buy clothes in bigger shopping centres, because all stores are in one place and the shopping is quicker. In particular, the younger ones also buy online, while the elderly still have a high level of mistrust when buying online. The smallest group of them buy through catalogue sales and boutiques of 


\begin{tabular}{|l|c|}
\hline \multicolumn{2}{|c|}{ PLACE OF BUYING CLOTHES } \\
\hline \multicolumn{1}{|c|}{ Place of buying clothes } & $\begin{array}{c}\text { Number } \\
\text { of answers (\%) }\end{array}$ \\
\hline $\begin{array}{l}\text { Bigger shopping centres and } \\
\text { department stores }\end{array}$ & 34 \\
\hline In smaller stores in the city centre & 20 \\
\hline On the Internet & 19 \\
\hline Abroad & 16 \\
\hline In boutiques of Slovenian designers & 6 \\
\hline On catalogue sales & 5 \\
\hline
\end{tabular}

THE FACTORS OF INFLUENCING THE PURCHASE

\begin{tabular}{|l|c|}
\hline \multicolumn{1}{|c|}{ Factors } & $\begin{array}{c}\text { Number } \\
\text { of answers (\%) }\end{array}$ \\
\hline Price & 28 \\
\hline Brand Name & 25 \\
\hline $\begin{array}{l}\text { It is important that the clothes are } \\
\text { suitable }\end{array}$ & 25 \\
\hline Quality & 15 \\
\hline Other & 7 \\
\hline On catalogue sales & 5 \\
\hline
\end{tabular}

Slovenian designers, as they are accessible only to a handful of users.

We also wanted to know how fashion-clothing brands are important in shopping.

Table 4

\begin{tabular}{|l|c|}
\hline \multicolumn{2}{|c|}{ IMPORTANCE OF FASHION CLOTHING BRANDS } \\
\hline $\begin{array}{c}\text { Importance of fashion } \\
\text { clothing brands }\end{array}$ & $\begin{array}{c}\text { Number } \\
\text { of answers (\%) }\end{array}$ \\
\hline Very important & 38 \\
\hline Important but not decisive & 35 \\
\hline Not important & 27 \\
\hline
\end{tabular}

When asked how important fashion clothing brands are to users, $38 \%$ of respondents said that brands were very important, $35 \%$ said they were important but not decisive, and $27 \%$ of respondents said that brands are not important.

The following question was related to the purchase of domestic and foreign brands

Table 5

\begin{tabular}{|l|c|}
\hline \multicolumn{2}{|c|}{ DOMESTIC AND FOREIGN BRANDS } \\
\hline $\begin{array}{c}\text { Buying domestic and foreign } \\
\text { brands }\end{array}$ & $\begin{array}{c}\text { Number } \\
\text { of answers (\%) }\end{array}$ \\
\hline Buying domestic and foreign & 45 \\
\hline Buying mostly foreign & 33 \\
\hline Buying mostly domestic & 12 \\
\hline It does not matter & 10 \\
\hline
\end{tabular}

The results showed that almost half of the shoppers buy domestic and foreign brands. Compared to whether or not they are buying more domestic or foreign brands, we see that foreign brands are in advantage because shoppers more often buy them than the domestic ones. This is because there are more foreign brands in Slovenia, few are home-made, but they are not well known to shoppers, because companies invest too little money in marketing communications in order to gain greater recognition.
We were also interested in what factors most influence shoppers when buying clothes.

The results showed that shoppers first look at the price, which is expected data in today's time and match the structure of the personal monthly income of the respondents, since most of them belong to the lower income group. The quality is only on the fourth place. As other, respondents indicated the lists of the packaging, the look of the product, the image of product, the colour of clothing and the clothing material. When we asked respondents what attracts consumers when buying clothes, the respondents said differently. The results are shown in the table 7 below.

Table 7

\begin{tabular}{|l|c|}
\hline \multicolumn{2}{|c|}{$\begin{array}{c}\text { THE FACTORS OF ATTRACTION WHEN } \\
\text { PURCHASING PARTICULAR CLOTHES }\end{array}$} \\
\hline \multicolumn{1}{|c|}{ Factors } & Number of answers (\%) \\
\hline Design & 33 \\
\hline Brand Name & 18 \\
\hline Quality & 16 \\
\hline Need for a product & 16 \\
\hline Price & 11 \\
\hline Other & 6 \\
\hline
\end{tabular}

Most respondents said that they are first attracted by the design of the product, which is understandable, as even before the customer sees the price and quality of the product, the clothes can be seen from afar and then one look at the quality, price or brand name. The brand name is also very important, as it is the second most common answer. As other, the respondent stated the colour of the clothes, the clothing material and the fact that the clothes are displayed in the exhibition.

Where do shoppers get information about fashion clothing brands was our next question.

The table 8 shows that shoppers get the most information about brands on the Internet, which is logical, since the Internet has become an important factor in all other areas in the last decade. Friends and fashion shows are also an important source of information. The most common way to get information about brand is from newspaper and mail sent to home. As 
GETTING TO KNOW THE FASHION CLOTHING BRANDS

\begin{tabular}{|l|c|}
\hline \multicolumn{1}{|c|}{ Source of information } & Numberof answers (\%) \\
\hline On the Internet & 28 \\
\hline From friends & 21 \\
\hline In fashion shows & 16 \\
\hline From clothing sellers & 11 \\
\hline On television & 10 \\
\hline From newspapers & 5 \\
\hline From mail sent to home & 5 \\
\hline Other & 4 \\
\hline
\end{tabular}

other, respondents cited leaflets and outdoor advertising.

We were also interested how customers are loyal to individual brands.

Table 9

\begin{tabular}{|c|c|}
\hline \multicolumn{2}{|c|}{ LOYALTY TO BRAND NAME } \\
\hline Loyalty & $\begin{array}{c}\text { Number } \\
\text { of answers (\%) }\end{array}$ \\
\hline Very loyal & 35 \\
\hline Loyal until I find a better brand & 35 \\
\hline $\begin{array}{l}\text { I am not loyal because brands are } \\
\text { not important to me }\end{array}$ & 16 \\
\hline $\begin{array}{l}\text { I am not loyal because I like to } \\
\text { constantly change brands }\end{array}$ & 14 \\
\hline
\end{tabular}

The results showed that customers are very loyal to individual brands or are loyal at least as long as they do not find a better brand. It is therefore important that companies invest heavily in brand names and build a brand identity.

Trademark counterfeiting is widespread in the world, especially in the fashion brand of clothing and footwear. Replies of respondents to this question are shown in the table 10.

Nearly three quarters of respondents believe that trademark counterfeiting is ethically controversial, which is a positive thing. Buying a fake product instead of a recognized brand is a harmful act, because it can hide the exploitation of children and the possible use of toxic substances. It is an illegal act and through the Internet sale of counterfeit goods, it is spreading even faster. That is why it is

\begin{tabular}{|c|c|}
\hline \multicolumn{2}{|c|}{ TRADEMARK COUNTERFEITING } \\
\hline Trademark counterfeiting is & $\begin{array}{c}\text { Number } \\
\text { of answers (\%) }\end{array}$ \\
\hline Ethically controversial & 74 \\
\hline Not ethically controversial & 20 \\
\hline I do not know & 6 \\
\hline
\end{tabular}

important for consumers to be aware of what they are doing when they buy fake products.

Finally, we asked respondents about buying fake brands. $37 \%$ respondents said they had already purchased a fake brand and $62 \%$ ) had never bought.

Despite the fact that the majority believe that purchase, of a fake brand is ethically controversial, as many as $37 \%$ have purchased such products. Maybe that is so because the original products are much more expensive and more difficult to get it.

However, counterfeiting is also, in some ways, theft, as counterfeiters violate intellectual property laws. If someone buys such products, they can support the exploitation of children and finances illegal activities.

\section{CONCLUSIONS}

Fashion offers the consumers the ability to express individuality and has been constantly changing and bringing about novelties throughout history. A successful fashion clothes brand must evoke positive feelings for the consumer, and must represent confidence, quality, reliability and prestige. Therefore, companies need to design and build strong brands, with a clear identity. In the fashion industry, brands are particularly important as competition is high and businesses need to attract and retain new customers. Successful branding requires a good knowledge of consumers and their purchasing processes.

In the fashion industry, understanding the concept of fashion marketing is extremely important, as companies face great competition from new products. The domestic supply of clothing is relatively modest. The main reason is that in Slovenia there are just a few Slovenian clothes brands of average quality that would be accessible to most consumers. We have some top designers who design prestigious fashion clothes for only a handful of individuals. The supply of foreign clothing brands is very good in Slovenia, because Slovenia is part of the European Union, where the range of different fashion clothing brands is huge from all over the world.

\section{REFERENCES}

[1] Easey, M., Fashion marketing. In: Wiley-Blackwall, Oxford, John Wiley \& Sons, Ltd., Publication, 2009

[2] Ismail, A.R., Spinelli, G., Effects of brand love, personality and image on word of mouth: The case of fashion brands among young consumers, In: Journal of Fashion Marketing and Management, 2012, 16, 4, 386-398

[3] Surchi, M., The temporary store: a new marketing tool for fashion brands, In: Journal of Fashion Marketing and Management, 2011, 15, 2, 257-270 
[4] Goworek, H., An investigation into product development processes for UK fashion retailers: A multiple case study, In: Journal of Fashion Marketing and Management, 2010, 14, 4, 648-662

[5] Burstiner, I., Basic retailing, In: Boston, Richard D. Irwin, Inc Homewood, 1991

[6] Berman, B.R., Evans, J.R., Retail Management: In: A Strategic Approach (12th Edition), Prentice Hall, 2012

[7] Kaczorowska-Spychalska, D., Shaping Consumer Behaviour in the Fashion Industry by Interactive Communication Forms, In: Fibres \& Textiles in Eastern Europe, 2018, 26, 4, 13-19

[8] O'Cass, A, McEwan, H., Exploring consumer status and conspicuous consumption, In: Journal of Consumer Behaviour, 2004, 4, 1, 25-39

[9] O'Cass, A., Siahtiri, V., Are young adult Chinese status and fashion clothing brand conscious? In: Journal of Fashion Marketing and Management, 2014, 18, 3, 284-300

[10] Han, Y.J., Nunes, J.C., Dre`ze, X., Signalling status with luxury goods: the role of brand prominence, In: Journal of Marketing, 2010, 74, 4, 15-30

[11] Aagerup, U., Scharf, E.R., Obese models' effect on fashion brand attractiveness, In: Journal of Fashion Marketing and Management, 2018, 22, 4, 557-570

[12] Dofles, G., Mode \& Modi, In: Zagreb, Golden marketing, 1997

[13] Kutsenkova Z., The Sustainable Future of the Modern Fashion Industry, In: Honour's Theses and Capstone Projects, 2017, 21

\section{Authors:}

BRUNO ZAVRŠNIK, VOJKO POTOČAN

University of Maribor, Faculty of Economics and Business, Razlagova 14, 2000 Maribor, Slovenia

$$
\text { Corresponding author: }
$$

BRUNO ZAVRŠNIK

e-mail: bruno.zavrsnik@um.si 